\title{
Association between cognitive impairment and criteria for frailty syndrome among older adults
}

\author{
Associação entre o comprometimento cognitivo e os critérios para a síndrome de \\ fragilidade em idosos
}

\author{
Allan Gustavo BRIGOLA',2, Ana Carolina OTTAVIANI', Danilo Henrique Trevisan CARVALHO³, Nathalia Alves \\ OLIVEIRA', Érica Nestor SOUZA', Sofia Cristina lost PAVARINI ${ }^{4}$
}

\begin{abstract}
The association between cognitive impairment and physical frailty has been studied in older adults. The criteria degree of frailty may be keys to associated cognitive impairment. Objective: To analyze the association between cognitive impairment and the criteria for frailty. Methods: We cross-sectionally examined data from 667 older adults ( $\geq 60$ years of age) from a study entitled 'Variables associated to cognition in elderly caregivers' involving patients in an urban and rural primary healthcare center. We defined cognitive impairment based on different groups of scores on the Mini Mental State Examination, and defined frailty and prefrailty using the criteria by the Cardiovascular Health Study. We performed multinomial regression models to analyze the association between levels of frailty and cognitive impairment. Results: Similar proportions of women (54.8\%) and men (45.2\%) participated in the study (mean age: 71 years old). We found cognitive impairment, prefrailty and frailty in 34,54 , and $24 \%$ of the participants, respectively. Concomitant cognitive impairment and frailty was found in 13\% of them. The chances of cognitive impairment increased up to 330\% (Odds Ratio [OR]: 4.3; 95\% confidence interval [95\%Cl] 2.4-7.7; $\mathrm{p}<0.001)$ among frail individuals, and 70\% (OR: 1.7; 95\% Cl 1.0-2.8; $\mathrm{p}=0.033$ ) among prefrail individuals compared to robust/nonfrail individuals. After controlling for age, education, place of residence and functional dependence, slowness and fatigue criteria were significantly associated with cognitive impairment. Conclusion: Older adults with frailty have a greater likelihood of concomitant cognitive impairment than prefrail and robust older adults. The prevalence of cognitive impairment and frailty is consistent with data reported in literature. The present findings contribute to the investigation of cognitive frailty.
\end{abstract}

Keywords: older adults; cognitive dysfunction; frailty.

\begin{abstract}
RESUMO
A associação entre comprometimento cognitivo e fragilidade tem sida estudada em idosos e os critérios de fragilidade e níveis de fragilidade podem também apresentar influência na função cognitiva. Objetivo: Analisar a associação entre comprometimento cognitivo e os critérios de fragilidade em idosos. Métodos: 0 estudo analisou transversalmente dados de 667 idosos ( $\geq 60$ anos) do estudo 'Variables associated to cognition in elderly caregivers' conduzido com usuários da atenção primária a saúde de áreas urbanas e rurais. Comprometimento cognitivo foi definido em função dos escores no Miniexame do Estado Mental baseado na escolaridade e a fragilidade e pré-fragilidade foi operacionalizada segundo os critérios do Cardiovascular Health Study. Foram realizados modelos de regressão multinominal para analisar a associação entre níveis de fragilidade e comprometimento cognitivo. Resultados: Proporções semelhantes de mulheres (54,8\%) e homens (45,2\%) participaram do estudo (média de idade: 71 anos). Comprometimento cognitivo, pré-fragilidade e fragilidade foram encontrados em 34,54 e $24 \%$ dos participantes, respectivamente. Concomitante comprometimento cognitivo e fragilidade foi evidenciado em 13\%. As chances de apresentar comprometimento cognitivo aumentaram em 330\% (Odds Ratio [OR]: 4.3; intervalo de confiança de 95\% [IC95\%] 2.4-7.7; p<0.001) entre indivíduos frágeis e 70\% (OR: 1.7; IC95\% 1.0-2.8; p=0.033) entre indivíduos pré-frágeis em comparação com indivíduos robustos/não-frágeis. Após controle da idade, escolaridade, local de residência e dependência funcional, os critérios de lentidão e fadiga foram significativamente associados ao comprometimento cognitivo. Conclusão: Os idosos mais frágeis têm maior probabilidade de apresentar comprometimento cognitivo comparados a adultos idosos pré-frágeis ou robustos. A prevalência de comprometimento cognitivo e fragilidade é consistente com os dados relatados na literatura e fornece suporte para futuras investigações sobre a fragilidade cognitiva.
\end{abstract}

Palavras-chave: idoso; disfunção cognitiva; fragilidade.

\footnotetext{
'Universidade Federal de São Carlos, Programa de Pós-Graduação em Enfermagem, São Carlos SP, Brazil.

${ }^{2}$ University of East Anglia, Faculty of Medicine and Health Sciences, United Kingdom.

${ }^{3}$ Universidade Federal de São Carlos, Programa de Pós-Graduação em Fisioterapia, São Carlos SP, Brazil.

${ }^{4}$ Universidade Federal de São Carlos, Departamento de Gerontologia, São Carlos SP, Brazil.
}

Allan Gustavo BRIGOLA ID https://orcid.org/0000-0003-0265-4940; Ana Carolina OTTAVIANI ID https://orcid.org/0000-0003-4037-4587; Danilo Henrique Trevisan CARVALHO iD https://orcid.org/0000-0002-1089-5739; Nathalia Alves OLIVEIRA iD https://orcid.org/0000-0003-1665-8109; Érica Nestor SOUZA iD https://orcid.org/0000-0002-7952-7643; Sofia Cristina lost PAVARINI ID https://orcid.org/0000-0001-9359-8600

Correspondence: Allan Gustavo Brigola; The Queen's Building, Faculty of Medicine and Health Sciences, University of East Anglia, Norwich Research Park, NR4 7TJ, United Kingdom; E-mail: allanbrig@gmail.com

Support: This paper was supported by São Paulo Research Foundation (Fundação de Amparo à Pesquisa do Estado de São Paulo - FAPESP) grant number \#2013/26798-9; \#2018/00265-8).

Conflict of interest: There is no conflict of interest to declare.

Received on January 9, 2019; Received in its final form on June 21, 2019; Accepted on August 6, 2019.

(cc) BY 
A slight decrease in cognitive function is expected during the ageing process. However, cognitive impairment can occur when one's performance regarding memory, judgment, language, and attention is lower than that expected for one's age and educational level ${ }^{1,2}$. Cognitive impairment can be caused by neurodegeneration, vascular problems and metabolic problems. Nonetheless, chronic stress, depressive symptoms and anxiety can contribute to a poorer mental performance during old age ${ }^{3}$. Lately, the poor physical function, such as frailty, is considered another strong factor linked to cognitive impairment, seen that these conditions share similar pathophysiological mechanisms on the cellular and systemic levels ${ }^{4,5}$.

Different theories and particular (but complementary) evaluations of frailty in older adults have contributed to the health care, to the comprehensive geriatric and gerontological assessment, and supported the interventions planning. The Cardiovascular Health Study (CHS) defined frailty as a geriatric syndrome that could be assessed using the measurement of five clinical criteria: unintentional weight loss, fatigue (exhaustion), muscle weakness, slow gait/slowness and low levels of physical activity ${ }^{6}$. More recently, Morley et al. contributed to the definition of the clinical syndrome as a multiple-cause condition that leads to vulnerability, functional dependence, and death ${ }^{7}$.

Other frailty theories and measures are also useful to predict cognitive impairment ${ }^{8}$. However, a physical examination using the CHS frailty clinical criteria ${ }^{6}$ may indicate changes in cognitive functions. Systematic reviews and meta-analyses confirmed the existence of a strong link between physical and cognitive impairment ${ }^{5,9,10}$. Although there is evidence associating frailty with cognitive impairment, a small number of studies on this subject have been conducted considering the five clinical criteria, individually, in low and middle-income countries.

In Brazil, an analysis of the FIBRA study described the criteria of slow gait speed (slowness) and low grip strength (weakness) as the strongest measures associated with cognitive performance among older adults ${ }^{11}$. A further FIBRA study analysis with 384 community-dwelling older adults confirmed that frailty and specific cognitive domains are linked, with a poorer performance as to time orientation and working memory prevalent among frail older adults ${ }^{12}$. Similar findings were observed in 737 participants of a study conducted in Rio de Janeiro City ${ }^{13}$ and in a multi-centric Brazilian study ${ }^{14}$. Older adults with frailty had consistently lower Mini Mental State Examination (MMSE) scores compared to prefrail and robust older adults ${ }^{13,14}$. A systematic review with 29,664 participants in 19 studies, which were mostly conducted in Latin America, found that memory is the main function affected in older adults with frailty, and slowness and weakness are the most prevalent frailty clinical criteria in cognitively impaired older adults ${ }^{15}$.

Despite the growing interest in investigating the association between cognitive and physical status, further studies should be conducted with older adults living in low and middle-income countries. Therefore, the aim of the present study was to analyze the association between cognitive impairment and the clinical criteria for frailty syndrome. We hypothesized that some frailty clinical criteria are strongly associated with cognitive impairment in older adults. Additionally, we want to confirm whether frailty presents a close association with cognitive impairment, compared to prefrailty and robust older adults.

\section{METHODS}

\section{Participants}

The present cross-sectional study is part of a study entitled "Variables associated with cognition in elderly caregivers" conducted by the Health and Ageing Group of Universidade Federal de São Carlos involving individuals registered in the Family Health Units of São Carlos City, São Paulo State, Brazil. São Carlos is in the Southeastern region of the country and has an estimated population of 221,950 residents, among whom $13 \%$ were aged 60 or older, according to the 2010 Brazilian census ${ }^{16}$.

The study was conducted between April and December of 2014. The participant selection process is described elsewhere ${ }^{3,17,18}$, but a brief description follows. All communitydwelling older adults (age $\geq 60$ in Brazil, as defined by the World Health Organization) registered at 18 primary healthcare centers $(n=1,188)$ in São Carlos City, Brazil, were contacted in person and invited to participate in the survey. Individuals with auditory, visual or language limitations that could constitute barriers to the data collection instruments were excluded. The response rate was $59.1 \%$. The survey was conducted with 351 community-dwelling older caregivers and 351 communitydwelling older non-caregivers (total: 702 individuals) registered with primary care services in rural and urban regions. For the present study, 667 individuals were included, and the single criterion for entry was having complete data available on demographics, cognitive and frailty status.

The present study was approved by the Human Research Ethics Committee of Universidade Federal de São Carlos (certificate number: 517.182) and all participants signed an informed consent. Household interviews were conducted by trained professionals in the fields of Gerontology and Nursing.

\section{Variables and evaluations}

1) Demographic characteristics: gender (male, female), age (continuous and age range), years of education (continuous and education level), retirement (yes, no), place of residence (rural, urban), and ethnicity (black/brown, white and others).

2) Activities ofdaily living (ADL):Functioning was assessed using the Lawton and Brody Scale to determine the degree of independence on basic activities, such as performing housework, handling money, using the telephone, administering 
medications, traveling, shopping and preparing full meals. The total score ranges from seven (complete dependence) to 21 (complete independence), with intermediate scores (8 to 20 points) indicative of partial dependence ${ }^{19,20}$.

3) Cognitive impairment: Cognitive screening was performed using the Mini Mental State Examination (MMSE), the score of which ranges from 0 to $30^{21}$. The cutoff points were adjusted for different levels of formal education: $<26$ for those with $\geq$ nine years of schooling; $<24$ for those with five to eight years of schooling, $<22$ for those with one to four years of schooling, and $<17$ for illiterate individuals ${ }^{22}$. Addenbrooke's Cognitive Examination - Revised (ACE-R; score: 0-100) was also used to assess global cognition ${ }^{23,24}$.

4) The frailty syndrome and criteria: The five frailty clinical criteria of the Cardiovascular Health Study were considered: unintentional weight loss in the past year, fatigue in the past week, muscle weakness, slowness and decreased physical activity levels when compared to the previous year. Unintentional weight loss in the past year, fatigue in the past week and decreased physical activity level were self-declared. Muscle weakness was assessed using a dynamometer and slowness, with the time required to walk 4.6 meters. Based on Fried's phenotype, the number of criteria was used to determine the level of frailty: frail ( from three to five criteria), prefrail (one or two criteria) and robust/non-frail (negative for all five criteria) ${ }^{6}$.

\section{Statistical analysis}

The Statistical Package for the Social Sciences - SPSS software, version 21.0 program was used for the data analysis. Descriptive statistics were performed to characterize the overall sample and the sample stratified by cognitive status. The values for frequency (n), percentage (\%), mean and standard deviation $( \pm)$ were calculated. The independent $t$-test was used to compare means and the chi-square test was used to compare categorical variables between groups according to gender (Table 1). The prevalence of simultaneous cognitive impairment and frailty was estimated with $95 \%$ confidence intervals $(95 \% \mathrm{CI})$. One-way ANOVA was used with Tukey's post hoc test for comparisons of MMSE scores between frailty levels (Figure 1).

Multinomial regression models were run to analyze the associations between frailty syndrome/criteria (independent variable) and cognitive impairment (dependent variable). Crude models were run to determine associations between age (continuous), education (continuous), gender (reference: male), place of residence (reference: rural), degree of dependence on ADL (reference: independent), unintentional weight loss, fatigue, weakness, slowness, low physical activity (reference: absence of criteria), prefrailty and frailty (reference: no frailty). Variables with a $p$-value $\leq 0.20$ were selected for the adjusted regression remodel. The first model (Table 2) included all criteria as controlling variables in the same model. Prefrailty (Model B) and frailty (Model C) were incorporated independently in adjusted models. Associations with a p-value $\leq 0.05$ were considered statistically significant.

\section{RESULTS}

Among the 702 participants, 35 were excluded from the analysis due the missing data on education, cognitive and frailty status. The sample consisted of similar proportions of women $(54.8 \%)$ and men $(45.2 \%)$. Women tended to be younger (mean difference: -1.6 years; $p=0.012$ ), more independent regarding $\mathrm{ADL}$ (w: $33.6 \%$ vs. $\mathrm{m}: 8 \%$ ) and fewer were retired compared to men (w: $64.5 \%$ vs. m: $91.7 \%$ ). Women also had higher proportions of slowness (w: $27 \%$ vs. m: $18.3 \%$ ) and low physical activity compared to men (w: $54.9 \%$ vs. m: $47.2 \%$ ).

No differences between women and men were found regarding the prevalence of cognitive impairment (Table 1). Cognitively impaired older adults tended to be older (mean difference: 2.8 years; $\mathrm{p}<0.001$ ) than those with normal cognition. Regarding performance on ADL, $15.5 \%$ of cognitively impaired and $25.4 \%$ of older adults with normal cognitive were completely independent. Regarding frailty, except for unintentional weight loss, all criteria were more prevalent in older adults with cognitive impairment.

The prevalence of simultaneous condition cognitive impairment and frailty was $13.2 \%$ (95\%CI 11-16) and the prevalence of concurrent cognitive impairment and prefrailty was 16.8 (95\%CI 14-20). Figure 1 displays the MMSE scores among the levels of frailty. The mean MMSE score was $23.9 \pm 3.8$ among robust individuals. Prefrail individuals had a poorer MMSE score compared to robust individuals (mean difference: $-1.5 ; \mathrm{p}<0.01)$, and the mean difference in the frail group compared to robust individuals was $-5.2(\mathrm{p}<0.01)$.

As shown in Table 2 and Figure 2, only fatigue/exhaustion and slowness remained associated with cognitive impairment in the model controlled for age, education, place of residence, dependence on $\mathrm{ADL}$ and other frailty criteria. Individuals with fatigue were 1.1 times more likely to exhibit cognitive impairment, when compared to those without this criterion. Moreover, individuals with slowness were 2.6 times more likely to exhibit cognitive impairment (Table 2; Model A). Frailty was more linked to cognitive impairment than prefrailty. The chances of cognitive impairment increased up to $330 \%$ in individuals with frailty (Model B) and 70\% in individuals with prefrailty, when compared to robust individuals (Model C).

\section{DISCUSSION}

One third of the participants presented cognitive impairment, one quarter was frail, and one half was prefrail. The analyses confirmed that frailty was strongly associated with cognitive impairment and fatigue, and that slowness seemed to be the clinical criteria associated with cognitive impairment.

The prevalence of cognitive impairment in the population-based SABE study in Brazil was $7.9 \%{ }^{25}$. In another study, the proportion of elderly people with some degree of cognitive impairment was $13.6 \%{ }^{26}$. Similar prevalence rates of 
frailty were found in other middle-income and low-income countries. In studies conducted in Colombia, the prevalence of frailty was $12.2 \%^{27,28}$. In Taiwan, the prevalence of frailty and prefrailty was $4.9 \%$ and around $40 \%$, respectively ${ }^{29}$. A systematic review analyzing 19 studies held in Latin America found that the prevalence of cognitive impairment ranged from 16 to $25 \%$, and frailty was present in $10 \%$ of the population $^{15}$. The proportion of cognitive impairment in studies may vary due to the profile of older adults in the sample, as well as the measures and cut-off points employed. In the present study, most participants had less than five years of schooling and the full version of MMSE was used. Moreover, clinical frailty criterion of low physical activity was more prevalent, which can be explained by the demographics, characterized as female and older, which are conditions associated with physical inactivity ${ }^{30}$.

In a study involving 2,375 Chinese older adults, the estimated prevalence of frailty with cognitive impairment was $1.8 \%$ and the estimated prevalence of prefrailty with cognitive impairment was $8.9 \%^{31}$. Half of the population had completed high school and scored significantly higher on the MMSE. Moreover, 61 participants were categorized with

Table 1. Characterization of participants stratified by cognitive status. São Carlos City, Brazil, 2014.

\begin{tabular}{|c|c|c|c|c|}
\hline Characteristic & Total $(n=667)$ & $\begin{array}{l}\text { Cognitively impaired } \\
\qquad(n=226)\end{array}$ & $\begin{array}{l}\text { Cognitively unimpaired } \\
\qquad(n=441)\end{array}$ & $\mathrm{p}$-value \\
\hline Male & $301(54.8)$ & $96(42.5)$ & 205 (46.5) & \multirow[t]{2}{*}{$0.184^{b}$} \\
\hline Female & $366(57.8)$ & $130(57.5)$ & $236(53.5)$ & \\
\hline Age, mean $( \pm)$ & $71.3(7.8)$ & $73.2(8.9)$ & $70.4(7.0)$ & $<0.001^{a}$ \\
\hline $60-69$ y.o., n (\%) & $328(49.2)$ & $95(42.0)$ & $233(52.8)$ & REF \\
\hline 70-79 у.о., n (\%) & $234(35.1)$ & $78(34.5)$ & $156(35.4)$ & $0.155^{b}$ \\
\hline$\geq 80$ y.o., n (\%) & $105(15.7)$ & $53(23.5)$ & $52(11.8)$ & $<0.001^{\text {b }}$ \\
\hline Education, mean $( \pm)$ & $3.6(3.5)$ & $3.1(3.5)$ & $3.9(3.5)$ & $0.006^{a}$ \\
\hline Illiterate, n (\%) & $147(22.0)$ & $56(24.8)$ & $91(20.6)$ & $0.477^{b}$ \\
\hline $1-4 y, n(\%)$ & $395(59.2)$ & $133(58.8)$ & $262(59.4)$ & $0.379^{b}$ \\
\hline $5-8 y, n(\%)$ & $62(9.3)$ & $14(6.2)$ & $48(10.9)$ & $0.065^{b}$ \\
\hline$\geq 9$ y, n (\%) & $63(9.4)$ & $23(10.2)$ & $40(9.1)$ & REF \\
\hline Retired, n (\%) & $512(76.7)$ & $180(79.6)$ & $332(75.3)$ & $0.121^{b}$ \\
\hline Rural residence, n (\%) & $166(24.9)$ & $48(21.2)$ & $118(26.8)$ & REF \\
\hline Urban residence, n (\%) & $501(75.1)$ & $178(78.8)$ & $323(7.2)$ & $0.070^{b}$ \\
\hline Black/Brown, n (\%) & $200(30.0)$ & $82(36.3)$ & $118(26.8)$ & NA \\
\hline White, n (\%) & $461(69.1)$ & $144(63.7)$ & $317(71.9)$ & NA \\
\hline Others, n (\%) & $6(0.9)$ & & $6(1.4)$ & NA \\
\hline Lawton ADL Scale, mean ( \pm ) & $16.8(4.0)$ & $14.7(4.6)$ & $17.8(3.1)$ & $<0.001^{a}$ \\
\hline Independent, n (\%) & $147(22.0)$ & $35(15.5)$ & $112(25.4)$ & REF \\
\hline Partially dependent, n (\%) & $493(73.9)$ & $169(74.8)$ & $324(73.5)$ & $0.002^{b *}$ \\
\hline Completely dependent, n (\%) & $27(4.0)$ & $22(9.7)$ & $5(1.1)$ & \\
\hline ACE-R, mean ( \pm ) & $58.6(20.7)$ & $41.7(18.4)$ & $67.3(16.0)$ & $<0.001^{\mathrm{a}}$ \\
\hline MMSE, mean ( \pm ) & $21.8(5.2)$ & $16.8(4.8)$ & $24.4(3.3)$ & $<0.001^{a}$ \\
\hline Unintentional weight loss, n (\%) & $165(24.7)$ & $65(28.8)$ & $100(22.7)$ & $0.052^{2}$ \\
\hline Fatigue, n (\%) & $169(25.3)$ & $87(38.5)$ & $82(18.6)$ & $<0.001^{b}$ \\
\hline Weakness, n (\%) & $268(30.2)$ & $116(51.3)$ & $152(34.5)$ & $<0.001^{b}$ \\
\hline Slowness, n (\%) & $154(23.1)$ & $90(39.8)$ & $64(14.5)$ & $<0.001^{b}$ \\
\hline Low physical activity, n (\%) & $343(51.4)$ & $133(58.8)$ & $210(47.6)$ & $0.004^{b}$ \\
\hline Robustness, n (\%) & $140(21.0)$ & $26(11.5)$ & $114(25.9)$ & REF \\
\hline Pre-frailty, n (\%) & $363(54.4)$ & $112(49.6)$ & $251(56.9)$ & $0.003^{b}$ \\
\hline Frailty, n (\%) & $164(24.6)$ & $88(38.9)$ & $76(17.2)$ & $<0.001^{b}$ \\
\hline Cognitive impairment+frailty, n (\%) & $88(13.2)$ & & & \\
\hline Cognitive impairment+prefrailty, n (\%) & $112(16.8)$ & & & \\
\hline
\end{tabular}

aSudent's t-test; 'bchi-square; REF: reference category; NA: variable not compared; MMSE: Mini Mental State Examination; ACE-R: Addenbrooke's Cognitive Examination-Revised; ADL: Activities of daily living; *Partially dependent/completely dependent analyzed together. 
frailty, using the frailty phenotype criteria, and the prevalence of cognitive frailty increased fivefold among individuals aged 75 and older ${ }^{32}$.

A Japanese study involving 4,207 participants found a $2.7 \%$ combined prevalence of MCI and frailty (3\% in women and $2.4 \%$ in men). This combination increased to $4.4 \%$ among

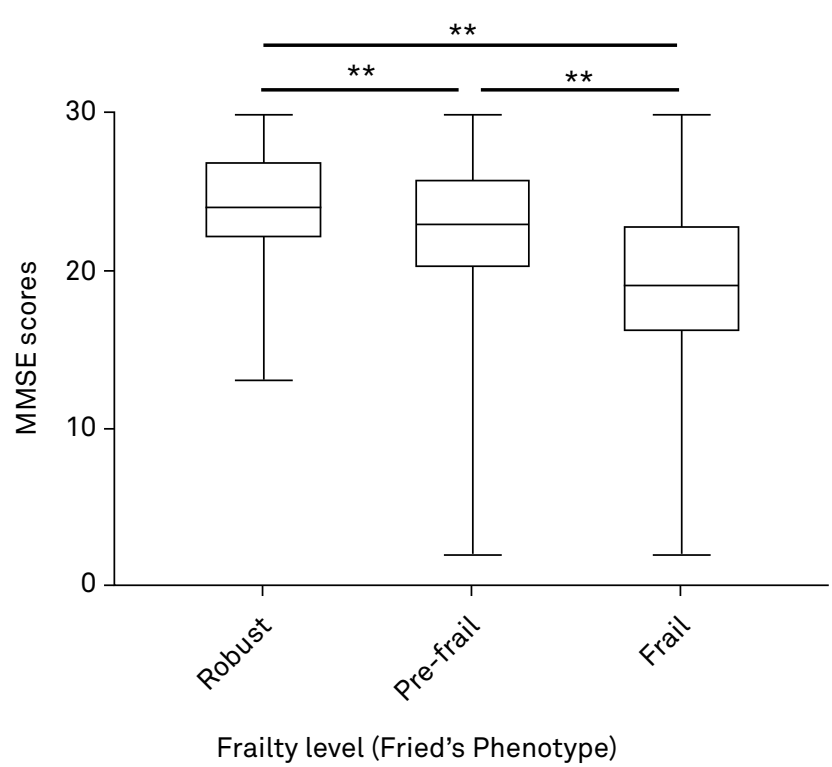

${ }^{* *} \mathrm{p} \leq 0.01$. MMSE: Mini Mental State Examination.

Figure 1. Box plot of performance on Mini Mental State Examination among robust, older adults with pre-frailty and frailty (n=667). São Carlos City, Brazil, 2014. individuals with a low level of schooling. The regression analysis adjusted by gender, age and education level showed that older adults with frailty had a $100 \%$ increased chance of presenting $\mathrm{MCI}^{33}$. In a study involving Chilean older adults, individuals with frailty had 3.93 times more chance of presenting $\mathrm{MCI}^{34}$. A study conducted in Brazil, with 51 prefrail and frail older adults used a similar MMSE cut-off. Frailty was treated as the dependent variable and global cognition explained up to $19 \%$ of the variation in the syndrome ${ }^{35}$. Furthermore, a longitudinal study demonstrated that $27.8 \%$ of non-frail individuals will not experience cognitive decline, whereas only $2 \%$ of frail older adults improve or stabilize their cognitive status ${ }^{8}$.

Frailty criteria also seem to be associated with cognitive impairment. A longitudinal survey involving 2,817 Japanese men showed that individual frailty factors were associated with a 16 to $18 \%$ reduction in their global cognitive status ${ }^{36}$. In another study, slowness and physical exhaustion (fatigue) were associated with a reduction in global $\operatorname{cognition}^{37}$. Slowness is the strongest frailty criterion associated to cognitive impairment, and this association has been frequently seen in literature. Additionally, in this study with 4,649 participants aged $\geq 50$, prefrail individuals $(n=1,444)$ had lower MMSE scores than robust individuals $(n=3,155)$, and frail individuals ( $\mathrm{n}=90$ ) had lower MMSE scores compared to the other two groups ${ }^{37}$. A study involving 395 American older adults found than an increase in walking speed was associated with a subsequent improvement in cognitive performance, especially recalling ${ }^{38}$. This finding underscores the

Table 2. Crude and adjusted regression models of association between criteria for frailty (Model A), prefrailty (Model B), frailty (Model C), and cognitive impairment (n=667). São Carlos City, Brazil, 2014.

\begin{tabular}{|c|c|c|c|c|c|c|}
\hline \multirow{2}{*}{ Variables } & \multicolumn{3}{|c|}{ Crude model } & \multicolumn{3}{|c|}{ Adjusted model } \\
\hline & OR & $95 \% \mathrm{Cl}$ & p-value & OR & $95 \% \mathrm{Cl}$ & $p$-value \\
\hline \multicolumn{7}{|l|}{ Model A } \\
\hline No Unintentional weight loss (ref) & 1.0 & & & 1.0 & & \\
\hline Unintentional weight loss & 1.3 & $0.9-1.9$ & 0.085 & 0.9 & $0.6-1.4$ & 0.877 \\
\hline No Fatigue (ref) & 1.0 & & & 1.0 & & \\
\hline Fatigue & 2.7 & $1.9-3.9$ & $<0.001$ & 2.1 & $1.4-3.2$ & $<0.001$ \\
\hline No Weakness (ref) & 1.0 & & & 1.0 & & \\
\hline Weakness & 2.0 & $1.4-2.7$ & $<0.001$ & 1.3 & $0.9-1.9$ & 0.143 \\
\hline No Slowness (ref) & 1.0 & & & 1.0 & & \\
\hline Slowness & 3.8 & $2.6-5.6$ & $<0.001$ & 2.6 & $1.7-4.0$ & $<0.001$ \\
\hline No Low physical activity (ref) & 1.0 & & & 1.0 & & \\
\hline Low physical activity & 1.5 & $1.1-2.1$ & 0.006 & 1,2 & $0.8-1.8$ & 0.190 \\
\hline \multicolumn{7}{|l|}{ Model B } \\
\hline Non-frailty (ref) & 1.0 & & & 1.0 & & \\
\hline Prefrailty & 1.9 & $1.2-3.1$ & 0.006 & 1.7 & $1.0-2.8$ & 0.033 \\
\hline \multicolumn{7}{|l|}{ Model C } \\
\hline Non-frailty (ref) & 1.0 & & & 1.0 & & \\
\hline Frailty & 5.0 & $3.0-8.5$ & $<0.001$ & 4.3 & $2.4-7.8$ & $<0.001$ \\
\hline
\end{tabular}

p-values in bold: statistically significant. For each model (A, B, C), age and education (continuous), gender (ref: male), setting (ref: rural), and ADL performance (ref: independent) were controlling variables. 
importance of measuring gait speed and other components of frailty to identify older adults at risk of dysfunctional cognition and its determinants ${ }^{39,40}$.

In Brazil, the FIBRA study conducted in a low-income community used the same MMSE cut-off as that used in the present study and found that weakness was associated with global cognitive impairment, whereas slowness was specifically associated with a poorer performance regarding verbal fluency and the clock drawing test ${ }^{11}$.

Some studies suggest biological pathways that may occur in both cognitive impairment and frailty. These mechanisms involve markers, such as sociodemographic clinical, inflammatory/immunity, and laboratorial characteristics, as well as proteins, metabolism/oxidative stress and genetics. Sociodemographic factors include advanced age, female gender, widowhood, low formal education and financial income ${ }^{5,41}$. Clinical factors, besides others, include cardiovascular conditions (diabetes, dyslipidemias and hypertension), nutritional deficiencies (malnutrition and vitamin D deficiency), functional dependence, hormonal dysregulation (reduction in testosterone and insulin resistance), inflammation and neurotoxic accumulation of the protein betaamyloid in the brain, loss of neurons of the substantia nigra, symptoms of depression, use of medications and other drugs, lifestyle and worse perception of health ${ }^{5,41}$.

The investigation of shared mechanisms in physiological conditions is a new field of study, which limits hypothesizing the pathways of clinical frailty criteria and the decline in cognitive functioning, despite the fact that the outcomes are known. Both frailty and cognitive impairment are risk factors for future adverse outcomes, such as dementia, disability, hospitalization and death. These outcomes have been confirmed in Brazilian and non-Brazilian older adults ${ }^{42,43,44,45}$.

The major limitation of the present study was the nonevaluation of dementia, which may affect the interpretation of results. The cross-sectional study design also limited us from knowing causal effects. On the other hand, one of the strengths of the study was the use of the MMSE with different cutoff points based on education level, which lends credibility to the assessment of cognition among the participants.

In conclusion, older adults with frailty scored lower on the MMSE than those individuals with prefrailty or robustness. Moreover, the prevalence of cognitive impairment, frailty and prefrailty in the present sample is consistent with data reported in literature. The frailty clinical criteria fatigue and slowness were associated to cognitive impairment; slowness seems to be the strongest criteria associated with this condition. The present findings contribute to the investigation of cognitive frailty in Brazil.

\section{ACKNOWLEDGMENTS}

We thank all the older adults who participated in the study.

\section{References}

1. Woodford HJ, George J. Cognitive assessment in the elderly: a review of clinical methods. QJM. 2007 Aug;100(8):469-84. https://doi. org/10.1093/qjmed/hcm051

2. Eshkoor SA, Hamid TA, Mun CY, Ng CK. Mild cognitive impairment and its management in older people. Clin Interv Aging. 2015 Apr;10:68793. https://doi.org/10.2147/CIA.S73922

3. Brigola AG, Luchesi BM, Alexandre T da S, Inouye K, Mioshi E, Pavarini SCl. High burden and frailty: association with poor cognitive performance in older caregivers living in rural areas. Trends Psychiatry Psychother. 2017 Oct/Dec;39(4):257-63. https://doi. org/10.1590/2237-6089-2016-0085

4. Aguilar-Navarro SG, Mimenza-Alvarado AJ, Anaya-Escamilla A, Gutierrez-Robledo LM. Frailty and Vascular Cognitive Impairment: Mechanisms Behind the Link. Rev Invest Clin. 2016 Jan/ Feb;68(1):25-32.

5. Sargent L, Nalls M, Starkweather A, Hobgood S, Thompson H, Amella EJ, et al. Shared biological pathways for frailty and cognitive impairment: A systematic review. Ageing Res Rev. 2018 Nov;47:14958. https://doi.org/10.1016/j.arr.2018.08.001

6. Fried LP, Tangen CM, Walston J, Newman AB, Hirsch C, Gottdiener J, et al. Frailty in older adults: evidence for a phenotype. J Gerontol A Biol Sci Med Sci. 2001 Mar;56(3):M146-56. https://doi.org/10.1093/ gerona/56.3.m146

7. Morley JE, Vellas B, van Kan GA, Anker SD, Bauer JM, Bernabei R, et al. Frailty consensus: a call to action.J Am Med Dir Assoc. 2013 Jun;14(6):392-7. https://doi.org/10.1016/j.jamda.2013.03.022

8. Mitnitski A, Fallah N, Rockwood MRH, Rockwood K. Transitions in cognitive status in relation to frailty in older adults: a comparison of three frailty measures. J Nutr Health Aging. 2011 Dec;15(10):863-7. https://doi.org/10.1007/s12603-011-0066-9

9. Robertson DA, Savva GM, Kenny RA. Frailty and cognitive impairment--a review of the evidence and causal mechanisms. Ageing Res Rev. 2013 Sep;12(4):840-51. https://doi.org/10.1016/j. arr.2013.06.004

10. Borges MK, Canevelli M, Cesari M, Aprahamian I. Frailty as a predictor of cognitive disorders: A systematic review and metaanalysis. Front Med (Lausanne). 2019;6:26. https://doi.org/10.3389/ fmed.2019.00026

11. Yassuda MS, Lopes A, Cachioni M, Falcao DVS, Batistoni SST, Guimaraes $\vee V$, et al. Frailty criteria and cognitive performance are related: data from the FIBRA study in Ermelino Matarazzo, Sao Paulo, Brazil. J Nutr Health Aging. 2012 Jan;16(1):55-61. https://doi. org/10.1007/s12603-012-0003-6

12. Macuco CRM, Batistoni SST, Lopes A, Cachioni M, da Silva Falcao DV, Neri AL, et al. Mini-Mental State Examination performance in frail, pre-frail, and non-frail community dwelling older adults in Ermelino Matarazzo, Sao Paulo, Brazil. Int Psychogeriatr. 2012 Nov;24(11):1725-31. https://doi.org/10.1017/S1041610212000907

13. Faria C de A, Lourenco RA, Ribeiro PCC, Lopes CS. [Cognitive performance and frailty in older adults clients of a private health care plan]. Rev Saude Publica. 2013 Oct;47(5):923-30. https://doi. org/10.1590/s0034-8910.2013047004451

14. Neri AL, Yassuda MS, Araujo LF, Eulalio MC, Cabral BE, Siqueira MEC, et al. Metodologia e perfil sociodemográfico, cognitivo e de fragilidade de idosos comunitários de sete cidades brasileiras: Estudo FIBRA. Cad Saude Publica. 2013;29(4):778-92. http://dx.doi. org/10.1590/S0102-311X2013000400015 
15. Brigola AG, Rossetti ES, dos Santos BR, Neri AL, Zazzetta MS, Inouye K, et al. Relationship between cognition and frailty in elderly: A systematic review | Relação entre cognição e fragilidade em idosos: uma revisão sistemática. Dement Neuropsychol. 2015 AprJun;9(2):110-9. https://doi.org/10.1590/1980-57642015DN92000005

16. Instituto Brasileiro de Geografia e Estatística. Censo Demográfico 2010; 2010. Available from: http://www.ibge.gov.br/home/estatistica/ populacao/censo2010/default.shtm

17. Luchesi BM, Alexandre TDS, De Oliveira NA, Brigola AG, Kusumota $\mathrm{L}$, Pavarini SCl, et al. Factors associated with attitudes toward the elderly in a sample of elderly caregivers. Int Psychogeriatrics. 2016 Dec;28(12):2079-89. https://doi.org/10.1017/S1041610216001538

18. Pavarini SCl, Brigola AG, Ottaviani AC, Luchesi BM, Souza ÉN, Rossetti ES, et al. Factors associated with cognitive performance in elderly caregivers. Arq Neuropsiquiatr. 2018 Oct;76(10):685-91. https://doi.org/10.1590/0004-282X20180101

19. Lawton MP, Brody EM. Assessment of older people: self-maintaining and instrumental activities of daily living. Gerontologist. 1969;9(3):179-86. https://doi.org/10.1093/geront/9.3_Part_1.179

20. Santos RL dos, Virtuoso Júnior JS. Reliability of the Brazilian version of the Scale of Instrumental. Rev Bras Promoç Saúde. 2008 Dec;21(4):290-6.

21. Folstein MF, Folstein SE, McHugh PR. "Mini-mental state". A practical method for grading the cognitive state of patients for the clinician. $J$ Psychiatr Res. 1975 Nov;12(3):189-98. https://doi.org/10.1016/00223956(75)90026-6

22. Brucki SMD, Nitrini R, Caramelli P, Bertolucci PHF, Okamoto IH. Suggestions for utilization of the mini-mental state examination in Brazil. Arq Neuro-Psiquiatr. 2003 Sep;61(3B):777-81. http://dx.doi. org/10.1590/S0004-282X2003000500014

23. Mioshi E, Dawson K, Mitchell J, Arnold R, Hodges JR. The Addenbrooke's Cognitive Examination Revised (ACE-R): a brief cognitive test battery for dementia screening. Int J Geriatr Psychiatry. 2006 Nov;21(11):1078-85. https://doi.org/10.1002/gps.1610

24. Carvalho VA, Caramelli P. Brazilian adaptation of the Addenbrooke's Cognitive Examination-Revised (ACE-R). Dement Neuropsychol. 2007 Apr/ Jun;1(2):212-6. http://dx.doi.org/10.1590/s1980-57642008dn10200015

25. Dias EG, Andrade FB de, Duarte YA de O, Santos JLF, Lebrao ML. Advanced activities of daily living and incidence of cognitive decline in the elderly: the SABE Study. Cad Saude Publica. 2015 Aug;31(8):1623-35. https://doi.org/10.1590/0102-311X00125014

26. Gondim AS, Coelho Filho JM, Cavalcanti AA, Roriz Filho JS, Nogueira CB, Peixoto Junior AA, et al. Prevalence of functional cognitive impairment and associated factors in Brazilian community-dwelling older adults. Dement Neuropsychol. 2017 Jan/Mar;11(1):32-9. http:// dx.doi.org/10.1590/1980-57642016dn11-010006

27. Curcio C-L, Henao G-M, Gomez F. Frailty among rural elderly adults. BMC Geriatr. 2014 Jan;14:2. https://doi.org/10.1186/1471-2318-14-2

28. Curcio C-L, Gomez F, Reyes-Ortiz CA. Activity restriction related to fear of falling among older people in the Colombian Andes mountains: are functional or psychosocial risk factors more important? J Aging Health. 2009;21(3):460-79. https://doi. org/10.1177/0898264308329024

29. Wu Y-H, Liu L-K, Chen W-T, Lee W-J, Peng L-N, Wang P-N, et al. Cognitive function in individuals with physical frailty but without dementia or cognitive complaints: results from the I-Lan longitudinal aging study. J Am Med Dir Assoc. 2015 Oct;16(10):899.e9-16. https:// doi.org/10.1016/j.jamda.2015.07.013

30. Gomes GAO, Luchesi BM, Gratão ACM, Orlandi FS, Say KG, Inouye K, et al. Prevalence of physical inactivity and associated factors among older caregivers of older adults. J Aging Health. 2019 Jun;31(5):793813. https://doi.org/10.1177/0898264318756422
31. Feng L, Zin Nyunt MS, Gao Q, Feng L, Yap KB, Ng T-P. Cognitive frailty and adverse health outcomes: findings from the Singapore Longitudinal Ageing Studies (SLAS). J Am Med Dir Assoc. 2017 Mar;18(3):252-8. https://doi.org/10.1016/j.jamda.2016.09.015

32. Feng L, Nyunt MSZ, Gao Q, Feng L, Lee TS, Tsoi T, et al. Physical frailty, cognitive impairment, and the risk of neurocognitive disorder in the Singapore longitudinal ageing studies. J Gerontol A Biol Sci Med Sci. 2017 Mar;72(3):369-75. https://doi.org/10.1093/gerona/glw050

33. Shimada H, Makizako H, Doi T, Yoshida D, Tsutsumimoto K, Anan Y, et al. Combined prevalence of frailty and mild cognitive impairment in a population of elderly japanese people. J Am Med Dir Assoc. 2013;14(7):518-24. http://dx.doi.org/10.1016/j.jamda.2013.03.010

34. Albala C, Lera L, Sanchez H, Angel B, Márquez C, Arroyo P, et al. Frequency of frailty and its association with cognitive status and survival in older Chileans. Clin Interv Aging. 2017 Jun;12:995-1001. https://doi.org/10.2147/CIA.S136906

35. da Silva Alves BB, de Oliveira Barbosa E, de Moraes Pimentel D, Carneiro LSF, Rodrigues ACMA, Deslandes AC, et al. Comparison of cognitive functions among frail and prefrail older adults: a clinical perspective. Int Psychogeriatrics. 2019 Feb;31(2):297-301. https:// doi.org/10.1017/S1041610218000765

36. Armstrong JJ, Godin J, Launer LJ, White LR, Mitnitski A, Rockwood $\mathrm{K}$, et al. Changes in frailty predict changes in cognition in older men:The Honolulu-Asia Aging Study. J Alzheimers Dis. 2016 Jun;53(3):1003-13. https://doi.org/10.3233/JAD-151172

37. Robertson DA, Savva GM, Coen RF, Kenny R-A. Cognitive function in the prefrailty and frailty syndrome.J Am Geriatr Soc. 2014 Nov;62(11):2118-24. https://doi.org/10.1111/jgs.13111

38. Krall JR, Carlson MC, Fried LP, Xue Q-L. Examining the dynamic, bidirectional associations between cognitive and physical functioning in older adults. Am J Epidemiol. 2014 Oct;180(8):838-46. https://doi.org/10.1093/aje/kwu198

39. Artaud F, Singh-Manoux A, Dugravot A, Tzourio C, Elbaz A. Decline in fast gait speed as a predictor of disability in older adults. J Am Geriatr Soc. 2015 Jun;63(6):1129-36. https://doi.org/10.1111/ jgs.13442

40. Ávila-Funes JA, Pina-Escudero SD, Aguilar-Navarro S, GutierrezRobledo LM, Ruiz-Arregui L, Amieva H. Cognitive impairment and low physical activity are the components of frailty more strongly associated with disability.J Nutr Health Aging. 2011 Aug;15(8):683-9. https://doi.org/10.1007/s12603-011-0111-8

41. Halil M, Cemal Kizilarslanoglu M, Emin Kuyumcu M, Yesil Y, Cruz Jentoft AJ. Cognitive aspects of frailty: mechanisms behind the link between frailty and cognitive impairment. J Nutr Health Aging. 2015 Mar;19(3):276-83. https://doi.org/10.1007/s12603-014-0535-z

42. Montero-Odasso MM, Barnes B, Speechley M, Muir Hunter SW, Doherty TJ, Duque G, et al. Disentangling Cognitive-Frailty: Results from the Gait and Brain Study. J Gerontol A Biol Sci Med Sci. 2016 Nov;71(11):1476-82. https://doi.org/10.1093/gerona/glw044

43. Dumurgier J, Artaud F, Touraine C, Rouaud O, Tavernier B, Dufouil C, et al. Gait Speed and Decline in Gait Speed as Predictors of Incident Dementia.J Gerontol A Biol Sci Med Sci. 2017 May;72(5):655-61. https://doi.org/10.1093/gerona/glw110

44. Aprahamian I, Suemoto CK, Aliberti MJR, de Queiroz Fortes Filho S, de Araujo Melo J, Lin SM, et al. Frailty and cognitive status evaluation can better predict mortality in older adults? Arch Gerontol Geriatr. 2018 Jul;77:51-6. https://doi.org/10.1016/j.archger.2018.04.005

45. Aliberti MJR, Cenzer IS, Smith AK, Lee SJ, Yaffe K, Covinsky KE. Assessing Risk for Adverse Outcomes in Older Adults: The Need to Include Both Physical Frailty and Cognition. J Am Geriatr Soc. 2019 Mar;67(3):477-83. https://doi.org/10.1111/jgs.15683 